\title{
Customer Behaviour and Sentiment Due to The COVID-19 Global Pandemic
}

\author{
Margita Majercakova1, and Maria Rostasova ${ }^{2 *}$ \\ ${ }^{1}$ University of Zilina, Faculty of Operation and Economics of Transport and Communications, \\ Department of communication, Univerzitna 1, 01026 Zilina, Slovakia \\ ${ }^{2}$ University of Zilina, Faculty of Operation and Economics of Transport and Communications, \\ Department of communication, Univerzitna 1, 01026 Zilina, Slovakia
}

\begin{abstract}
.
Research background: Identifying customer behaviour is one of the most critical activities in the implementation and evaluation of the analytical phase of the company's algorithm for marketing activities. Analyses are performed based on of research activities aimed at identifying the psychological processes of an individual, related to the selection of goods and services to meet his needs and desires, the distribution of his available resources (money, time, effort) into items related to consumption and overall perception and thinking of the customer in a specific time period. The emergence of a global crisis, Covid-19, has significantly changed consumer behaviour in the market, shopping motives and consumer sentiment. This aspect has prompted several studies that have placed great emphasis on identifying factors influencing customer behaviour during this specific period.

Purpose of the article: The article presents the results of these analyses, which were carried out during the initial stages of the emergence and spread of the pandemic.

Methods: The methods used to address this issue were based on the analysis, synthesis and comparison of data obtained by primary and secondary research, as well as the use of methods of deduction and induction, to draw general and specific conclusions related to the topic.

Findings \& Value added: he results of the findings not only confirm the expected change in customer behaviour in times of crisis, but the added value of solving this problem is to obtain important evidence for immediate decision-making and management of companies in times of crisis caused by "force majeure".
\end{abstract}

Keywords: customer behaviour; crisis situation; COVID-19 pandemic; consumer sentiment

JEL Classification: $D 1 ; M 1 ; M 3$

\footnotetext{
*Corresponding author: maria.rostasova@,fpedas.uniza.sk
} 


\section{Introduction}

Legacy and novel publications focusing on marketing strategy, tactics and operations $[1,2]$ states that the understanding of needs and wishes of the customers is one of the most important marketing goals. The research conducted in the field of customer behaviour focuses on how individuals, groups as well as organizations are choosing, buying, using and subsequently dealing with the goods, services, thoughts and experiences, which serve to satisfy their needs and wishes. It is very complicated to understand the decision making in the customer behaviour in so-called "ordinary situations" as they tend to behave differently to what they would declare as their needs and wishes in the majority of cases. Moreover, this decreases the possibilities of predicting and subsequently reacting to the dynamics of the consumer behaviour and their mood in the time of crisis, like a global pandemic, which was not created intentionally and therefore is a highly unpredictable situation on a global scale with extreme consequences.

Most of the people living in the current world were lucky enough for the past century as they were not affected by any global catastrophe. Based on the previous pandemics, we can reliably deduce that these or even similar events permanently changed the behaviour of the companies and their customers. The black death, which at the beginning of the 14th century was responsible for 30 million deaths in Europe alone, resulted in the end of the feudalism followed by the Age of Enlightenment that has considered wisdom, freedom and satisfaction as important values in human life and put them into the spotlight. The Spanish flu, which broke out in 1918, killed almost 100 million inhabitants in total. Consequently, it resulted in the speed-up of the statutory healthcare system and started an era of employercovered insurance in the US. Multiple countries admitted a necessity of international coordination for public healthcare after that. During the Second World War, an emancipation era emerged with women starting to work in factories. After the end of the war, the men came home and were followed by a generation of "baby-boomers" in the following years. A few decades later, the 9/11 attack in 2001 in New York changed people's opinions about travel safety and initiated a debate about how much privacy they are willing to give up in exchange for safety. Since then, the implemented changes never returned to the previous state.

\section{Analysis of current state in the solution of the issue}

In case we would like to deduct any applicable conclusion regarding consumer behaviour and moods, which has a significant effect on the profit and competitiveness of the companies, it is important to demonstrate the knowledge in the area from the viewpoint of both the domestic and foreign experts.

Ruth Maria Stock, Wayne D. Hoyer [3] gave more in-depth insights into the construction of the customer orientation on the individual level. They have pointed out the differences in customer behaviour and investigated the direct and indirect effects on the attitudes of customers.

They have put into the foreground the positive mitigating effects of empathy, reliability and expertise and identified connections between customer-oriented attitude, customeroriented behaviour and so-called "mitigating" effect of restrictions from the viewpoint of companies, representing the market offer for the customer. The results confirmed the very first expectations of the authors that the customer-oriented attitude has a direct effect on the customer's satisfaction. Other authors Chatura Ranaweera, Gordon McDougall and Harvir Bansal [4] presented and accepted the statement about the possibility of false results from the on-line observation based on overall customer behaviour, because the behaviour may differ significantly among the groups of individuals. 
They have proposed a theoretical model that captures the main characteristics of web pages and explains, how the user perception of the web pages could change, given a collection of user's characteristics. Moreover, they have also confirmed the influence of the design of the web page on the customer decisions, mainly in the $\mathrm{B} 2 \mathrm{C}$ context. Complex understanding of these user's characteristics will allow researchers to better understand customer behaviour in online shopping in the initial transaction, which presents the biggest challenge for the service providers. Understanding the user's characteristics will help the providers of goods and services to design the web pages better to achieve competitive advantage.

Dixon, M. and Thompshon, G. [5] have shown that already in the past that the researchers found the proof that the customers consider so-called "the usefulness of sequence of steps", which present satisfaction with accomplishing previous requirements, which they had on the service provider when evaluating their experience with services. In particular, they confirm that positioning of the top event, the usefulness of the final event and form of the service in individual events influence overall behaviour and perception of customers over time. They have suggested an optimal approach that would maximize the positive customer experience and perception. The level of the quality of the services perceived by the customer has a significant influence on the customer's satisfaction; perception of a customer relationship has a positive influence on the satisfaction, while the trust is the most important indicator; satisfaction of a customer positively relates to customer's behaviour that results in loyalty to the provider of services or supplier of the goods. Radu, V. [6] reacts on the complexity of the understanding of this issue, who defines the study of customer behaviour as a study of demand representatives (customers) and processes, which are used in selection, usage and consumption of goods and services including emotional, mental and behavioural customer's reactions. Customer behaviour includes thoughts of multiple sciences from areas like psychology, biology, chemistry and economics.

Tracking of the customer's moods and shopping behaviour was in the centre of the focus for many experts as well as analytical organizations. For example, Turzo, J. [7], just like many other authors, has shown how the novel coronavirus changed the functioning of economics. He took a closer look into the four elements in retail, which were irreversibly affected by the pandemics and how they could adjust to these changes. The positive side effect is that many companies have invested considerable resources, know-how and energy into the actions against the pandemic. The interesting results of his research showed the change in the track and speed of the customer shopping. In case when the customer runs out of supplies and decides to go shopping again, we can see differences in track and speed of the customer's shopping, both before and after the adoption of the government regulations (we talk about an allowance of 1 person per $25 \mathrm{sqm}$ ). However, the adoption did not have a significant impact on the duration of shopping, because customers tend to make the longer track faster. The length of the customer's track has increased by 15 percent and the speed of shopping by 20 percent at the beginning of the pandemics. In other words, the customers walked more in a shorter time. However, after the adoption of government regulations about the restriction on the number of customers in a store, the length of the track and speed returned immediately back to the previous values, typical for the period before pandemics. Turzo has also pointed out the topic of hours reserved for seniors. From 9 AM until 12 noon, the stores were reserved only for seniors. Mornings are dominant in the case of the length of the track, which was not always the rule before restrictions. It also served as proof that the seniors make use of the restricted times. As a consequence, the average speed of shopping at these times was significantly lower. The seniors tend to go around the store with lower speed as they are not in a rush. This safety measure had a significant impact on the crowdedness of the store. The collected data confirmed the hypothesis that three hours 
might be a potentially too long time for restricted shopping hours for one age group because the crowdedness of the store was very low at this time. The crowdedness declined in average by 23 percent in comparison to the previous state without any restrictions. The third hour, between $11 \mathrm{AM}$ and 12 noon, was the weakest one from an attendance perspective.

Same aspects were pointed out by Sheth, J., [8], who aimed at answering a question whether customers will return to their old habits after the end of pandemics or rather they will develop new ones despite technological advancements, changes in demographic characteristics and despite innovations, which resulted in the dismissal of work, recreational and educational boundaries in decision making.

Many researchers focused on the connection between the usage of social networks and shopping preferences long before the pandemic's breakout. Vithayathil, J. et al. [9] described in detail the levels of usage of popular platforms on social networks in regards to consumer behaviour. Similarly, Schaarschmidt, M. and Konsgen, R., [10] and many others focused on social networks and their influence on human behaviour, in this case, the employees. The main aim was to measure the extent of influence of the company on the behaviour of employees that deal directly with customers and have a high impact on their consumer behaviour.

The ever-growing popularity of virtual reality and the possibility of its application in many human activities, including grocery shopping, performed on a daily basis, drew the attention of researchers. Lombart, $\mathrm{C}$ et al. [11] pointed out the benefits of virtual reality for a better understanding of consumer behaviour. The topic of groceries and their safety is also mentioned in Szymkowiaka, A. et al. [12] and is very important in the time of the pandemics, Covid-19. The authors have found out the importance of individual attributes of the grocery item (usage of preservatives, processing methods, expiration date and nutritional value) and their relation in regard to shopping behaviour of individual customer segments. Interesting phenomena is that the results have shown inconsistency between consumer attitudes and individual attributes in regards to their shopping behaviour. Processing methods have been shown as the most important attribute and the expiry date as one of the least important attributes.

Interesting results were also presented by an analytical company Pygmalions [13], which besides many other features, monitored the customer behaviour in the stores using heat maps. The heat map shows places where the people spend most time in red colour. One of the consequences of the adoption of government regulation was that the customer did not wait that long at the cash registers anymore as the store was less crowded. However, before the customer spent there most of the time (red colour).

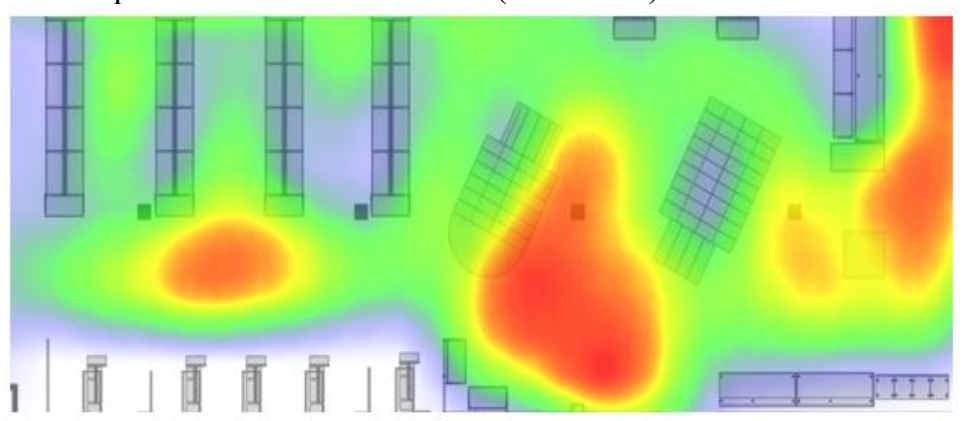

Fig. 1. Crowded zones before the adoption of restrictions

The spots around the cash register were less crowded after the adoption of regulations. This finding is an excellent example of social distancing in practice. The customers spend less time at cash registers and prefer to wait until a waiting queue is empty. 


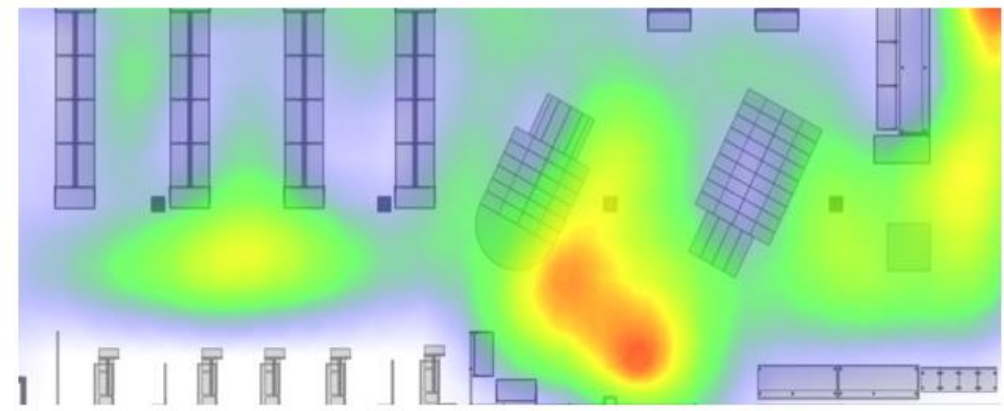

Fig. 2. Crowded zones after the adoption of restrictions

The study of customer behaviour is very important even in the times of the pandemic as in this way the retailers can better understand what influences shopping decisions. The understanding of how the customers decide which product to buy helps them to fill the blanks in the markets by identifying useful and demanded products.

In the article "Sociálny dištanc proti koronavírusu môže trvat' až do roku 2022, hovoria vedci" magazine Forbes [14] states that the coronavirus has already forced the companies to speed up the digital transformation, for example, the boom was triggered in the telemedicine and other applications for patient's appointments booking, while adoption by both doctors and insurance companies was previously slower. Similarly, companies began donating more significant amounts to charities, not to mention how the current situation helped millions of employees with a transition to the home office. Due to these changes, which happened at an extreme pace, a new customer segment was created. They are digitalonly. They may not even realize it, but when they return to the previous state nothing will be like previously. The people will not behave in the store in the same way as previously. They will not be keen on trying out a new type of cheese in the aisles of stores, and neither will a woman be willing to try a lipstick that may have been previously tried by other women. Maybe they will require fashion malls to disinfect clothing before they try it out in the fitting room. It is also questionable whether they will be willing to touch the touchscreens in the stores. Approximately 5 percent of people in the US lost a close relative due to the coronavirus. Yet another 18 percent of people know someone whose health was affected by the virus. In China or Italy, these numbers are much higher, approximately one third of the population have a close relative who was infected by a coronavirus. Millions of people lost their jobs, and billions of people were sent to home isolation. Not even talking about the fact that every one of us has gone through anxiety about a precarious situation or fear for a loved one and realized our own vulnerability.

Approximately 22 percent of people state that they suffer from anxiety due to home isolation, while younger people between the age of 18 and 24 suffer from anxiety in more than a third of the cases. Not talking about suffering that fifth of the seniors over 65 years, experiences. Social distancing against coronavirus can last up to the year 2022. Another 19 percent of people are worried that they will end up insolvent, while this is mostly experienced by young people up to 24 years old. The fact that 44 percent of people in the US did not believe in April that the government cannot cope with the problem did not help it either. In the context of such high numbers and mistrust in government, it is interesting to see that people instead tend to trust big corporations and believe in their crucial role in solving the crisis. Up to 62 percent of people believe that the crisis cannot be overcome without help from large corporations, while another 55 percent claims that the big corporations deal with coronavirus much better than the American government. Another important message for companies is the following finding. Up to 71 percent of people have expressed the opinion that if the company prefers its profits over the health of its 
employees, they lose interest in its products and they will never return back. It is no wonder that the customers are very cautious while shopping at the moment. Up to 37 percent of respondents say that they can secure all of their essential needs, including work, shopping or even socialization throughout various media and social networks. They also agreed that they do not need to visit physical stores throughout pandemics if it is not necessary. In case they are already shopping, they expect stores to take care of their health safety. This is followed by the results, such that up to 95 percent of customers expect stores to introduce safety measures for distancing, or that they will be provided with protective tools. Another 30 percent of people are planning to switch over to online shopping, including millennials and seniors above 65 years. The employers face another challenge as up to 36 percent of people who tried to work from home during the pandemics, would also prefer to do so afterwards. Such behaviour corresponds to the boom, which is experienced by technological companies offering various communication tools and platforms that allow for work from home. Companies that focus on the analysis of human behaviour are doing similarly well. The top tech companies are the ones who are hiring thousands of new employees, even during the corona crisis times. Amazon has approximately 20 thousand of open vacations in the technological field only. Moreover, it wants to hire the next 175 thousands of people for its logistics centres to be able to cope with the rising demand for online orders. Similarly, Facebook is hiring 10 thousand new employees and shopping application Instacart has 300 thousand open vacations. Naturally, it is challenging to satisfy such a demand for a workforce and therefore, the companies are more looking forward to robotization. For example, Wallmart already deployed machines that would clean the floor instead of the employees. South Korea uses robots for body temperature measurements and the hand sanitizer application when entering the stores. McDonald's is even testing robots for food preparation in the kitchen and serving the customers.

Jucha, P., Čorejová, T. [15] have focused on online marketplaces during the coronavirus in their research. They have followed up their previous work Corejová, T., et al. [16] in the field of digital transformation and its impact on the product's brand and services.

There are several methods out there, most commonly used in the research about customer behaviour. Therefore, some of the researchers are also focusing on the evaluation of the suitability of these methods. Huarng, $\mathrm{KH}$ [17] shows that the usage of regression analysis is typical in social sciences. However, usage of qualitative research method, e.g. structured qualitative analysis (SQA), in comparison to the regression method with usage of multiple data characteristics is indisputable.

\section{Contribution goal and methods}

Global pandemics logically inspired the formation of multiple studies that focused on the identification of factors influencing customer behaviour during such a specific period. The goal of the contribution is to introduce main results of these analyses and present the fundamental attributes of marketing activities, which are generally applicable, i.e. in addition to crisis situations, caused by e.g. global pandemics.

Methods used in solving this problem were created on the basis of analysis, synthesis and comparison of data of acquired research activities, as well as usage of methods of deduction and induction to draw general and specific conclusions on a given topic.

\section{Solution results}

The research activities that were oriented towards the impact of the pandemic on consumer behaviour, shopping decisions and customer's mood ruled the whole business sector. The 
results of the research were mostly of a non-existent nature without a significant focus on recommendations in terms of the necessary changes in the marketing strategy of companies operating in such or similar crisis situations.

In general, certain rules, aspects and facts have been in place for a long time, which are applied in a well-directed marketing strategy and tactics. Authors of this contribution have set a goal to pick examples of generally applicable aspects of consumer behaviour and simultaneously compare some (selected) consequences of COVID-19 pandemics onto the consumer mood in three various geographic areas as a result of multiple research activities and to propose some form of therapy applicable in marketing strategy and tactics of business subjects. The basis for this comparison is [18] research of consumer mood under the influence of COVID-19, conducted by company Datamar MNForce (2020). This institution regularly monitors expenses of the households that in pandemic times decreases their expenses, compares expenses on different product types and describes specific results of demographic segments and also provides an outlook for the economic situation of households for the period of six months. This company conducted a survey on the sample of 300 respondents in Moravian-Silesian region, Bratislava region and in the capital of Czech Republic - Prague. Respondents are selected to equally represent groups in regards to a different gender, age and income. The survey was realized in the second week of months April, May, June and July 2020. Main results of the comparison of selected findings described Table 1.

Table 1. Main results of the comparison of selected findings

\begin{abstract}
Universal marketing rule applicable outside of the crisis period:
Purchasing power plays an essential role in consumer behaviour. If you are not a billionaire, you will consider your budget when shopping. The products can be perfect, marketing can be done well, but if you do not have money for some particular product, you will not buy it. Segmentation of consumers according to their purchasing power can help the dealers to pick the right group of consumers and achieve better results.
\end{abstract}

\begin{tabular}{l|l|l|}
\multicolumn{1}{c|}{$\begin{array}{c}\text { Crisis period in Moravian- } \\
\text { Silesian region }\end{array}$} & \multicolumn{1}{c|}{$\begin{array}{c}\text { Crisis period in Bratislava } \\
\text { region }\end{array}$} & Crisis period in Prague \\
$\begin{array}{l}\text { The share of households, which } \\
\text { decreased their expenses during } \\
\text { the monitored months, was ever } \\
\text { decreasing. During the July } \\
\text { every fifth household was } \\
\text { expecting a decrease in } \\
\text { expenses. }\end{array}$ & $\begin{array}{l}\text { Customer optimism gradually } \\
\text { households expect spending } \\
\text { cuts in July. }\end{array}$ & $\begin{array}{l}\text { The "optimism" of Prague } \\
\text { consumers is reflected by a } \\
\text { significant decline in the share } \\
\text { of households that reduce their } \\
\text { spending. For the second } \\
\text { month in a row, this is } \\
\text { reflected in a fifth of } \\
\text { households. }\end{array}$ \\
\hline
\end{tabular}

Universal marketing rule applicable outside of the crisis period:

Important to consider: items, which were bought as well as the amount of every item. Necessary products are bought more often and in bulks, while the luxurious goods are bought less often in smaller quantities. The amount of every bought item is influenced by its expiration date, purchasing power, price, number of customers for whom the product is intended, etc. Analysis of shopping baskets can provide marketers with vast amounts of information about customer behaviour.

\title{
Crisis period in Moravian- Silesian region \\ Crisis period in Bratislava region \\ Crisis period in Prague
}

In goods with extended usage, households most often defer spending on cheaper goods, clothing, cheaper furniture and electronics. Restaurant services are well below the level achieved at the beginning of the crisis.
Share of households that defer expenses on goods of extended usage is decreasing mainly in clothing. Approximately the same level remains for cheaper furniture and electronics (up to 720 EUR). The deferment is very similar on the inter-monthly basis with goods of extended usage. There is an increase in demand for more expensive furniture. 


\section{Universal marketing rule applicable outside of the crisis period:}

Majority of the time, the customers tend to split their purchases into multiple stores, even if all the items might be available in one. For example, in their favourite supermarket: Even if the customer can find clothing and footwear there, he will most probably buy them at stores offering their favourite clothing brand. In case the customer has a possibility of buying the same items in multiple stores, the loyalty is lost, if it is not the only accessible store. Study of consumer behaviour from the location's viewpoint helps the dealers to identify the keyspots in the store.

\section{\begin{tabular}{l|l} 
Crisis period in Moravian- & Crisis period in Bratislava
\end{tabular}} Silesian region region

The share of households, which $\quad$ Approximately 60 percent of Inter-monthly there is no cut their expenses in households cut their costs in change in households that cut supermarkets, is 40 percent supermarkets in June and July. their costs in supermarkets, but already in the second month in a The increase in online stores in comparison to May they row. The increase in online decreased from 30 percent in have increased by 20 percent. shopping has increased and May to only 16 percent. stabilised at 30 percent.

\section{Universal marketing rule applicable outside of the crisis period:}

In case the customers investigate the product or services in more depth, their behaviour can reveal valuable information about benefits, properties, values and use-cases or problems that are the most important factors that influence their shopping decisions. If the customer relies more on one or more benefits than the others (e.g. safety), these required primary benefits are determining motivation factors, which control the purchase decision (product or service).

\begin{tabular}{|c|c|c|}
\hline $\begin{array}{l}\text { Crisis period in Moravian- } \\
\text { Silesian region }\end{array}$ & $\begin{array}{c}\text { Crisis period in Bratislava } \\
\text { region }\end{array}$ & Crisis period $\mathrm{i}$ \\
\hline $\begin{array}{l}\text { Most of the population change } \\
\text { their way of transport to work. } \\
\text { Significant increase in driving } \\
\text { causes problems in parking and } \\
\text { road capacities. }\end{array}$ & $\begin{array}{l}\text { In comparison to the time } \\
\text { before the crisis, three fourths } \\
\text { of Bratislava region inhabitants } \\
\text { changed their way of transport } \\
\text { to work. They tend to drive } \\
\text { more often or they work from } \\
\text { home. }\end{array}$ & $\begin{array}{l}\text { Three fourths of Prague } \\
\text { inhabitants changed their } \\
\text { transport to work. Most of the } \\
\text { respondents (almost one third) } \\
\text { state that they have started to } \\
\text { walk more. }\end{array}$ \\
\hline
\end{tabular}

\section{Conclusion}

In case we should present a question that should connect the topics of human behaviour and shopping moods, we can focus on multiple areas. In the time of this crisis, shopping behaviour is one of the factors that has an impact on the world trade in relations to GDP one of the markers of globalization. This marker has been on a downward trend since 2012 and anti-global political movements are growing in popularity. Javier Solana, representative of the European Union for foreign and security policy and NATO's secretary, became even more popular due to the statement in which he talks about reasons of untrust in globalization, of which there are many more in the time of pandemic than usual. Lack of the vital products - "from face masks to yeast" - shows low durability of the global supply market due to its excessive concentration in some countries justified by the lack of basic supplies. COVID-19 pandemics pointed out the limits of globalization but also the necessity for common solutions. Should we resist the temptation for a change in global production as a whole? Axioms of Adam Smith about specializations and David Ricard about comparative benefit are similarly truthful as they were two hundred years ago. What is necessary to do to prevent the lack of essential goods? Can a way be found by a transition from "just-in time" model to "just-in-case" model that prioritizes the security of supplies over the optimal cost-effectiveness? Do we have to require complete self-sufficiency or is it enough to have diversified global supply chains?

Even though our research (only in three very close geographical territories) neither had a goal and nor justified significant difference among consumer moods in individual tracked 
regions and the capital of Czech Republic, is it important to fight the inequality that was observed in individual countries in the world? Virus epidemics have been changing customer's shopping behaviour in different places. The changes were related to various levels of consumption, however, already now we know that there exist some thresholds in the shopping behaviour and customer's moods, understanding of which would be very helpful for marketers. The first threshold represents global proactive health-oriented purchasing, which has brought only small changes in business models. Already in the second threshold - reactive health control - the customers started stocking up with essential goods for ensuring health security (disinfectants, face masks). The continuation in the spread of the virus in the world caused transition into the third threshold - stocking up with groceries and other essential products. The fourth threshold resembles the shopping behaviour of consumers preparing for being quarantined - it is accompanied by testing of online-shopping infrastructure. The fifths threshold cannot be defined in other words than a restricted life (supply chain challenges make customers less sensitive to the prices of packaged goods in high demand or to those that guarantee hygiene standards). The sixth threshold means the life in novel life conditions (purchasing patterns during the crisis in the first stages of a pandemic will accelerate the adoption of a new, fundamental change in customers' shopping behaviour). The pandemic causes many changes in customer's shopping behaviour. It is essential to understand the changes, which happen in the second wave of pandemic and identify how long they will last after the end of pandemic (e.g. by affection vaccination). However, global customer knowledge will stay relevant and therefore, we should continue to acquire them, i.e. we should not decrease the intensity and depth of current acquisition.

However, globalization cannot be expressed only through markets. Opinions and tendencies are already emerging in the world that globalization cannot be limited to international trade and the free movement of financial capital. It talks about a need to focus on joint management, i.e. global public goods, which should be one of the main drivers of international cooperation. Globalization has created an understandable frustration and concerns of customers, which cannot be easily overcome by mentioning its great benefits, which it brought. Even the main topic of this contribution is to introduce an idea of the aim to create better globalization.

This article was supported by the: Granted project UNIZA - 8002/2020 - Supporting the emergence of innovation within the regional innovation ecosystem - creation and testing of a functional algorithm to evaluate the effectiveness of marketing communication between selected ecosystem stakeholders; VEGA V1/0152/18 Business and entrepreneurial models and platforms in a digital environment; VEGA 1/0055/21 Effective solutions in the postal sector during crises caused by "force majeure"

\section{References}

1. Kotler, P. (1998). Marketing Management. Czech Republic: Grada publishing.

2. Jiao, WL., Chen, H., Yuan, YF. (2020). Understanding users' dynamic behavior in a free trial of IT services: A three-stage model. INFORMATION \& MANAGEMENT, 57(6), Article Number 103238

3. Stock, RM., Hoyer, WD. (2005). An Attitude-Behavior Model of Salespeople's Customer Orientation. Journal of the Academy of Marketing Science, 33(4), 536-552.

4. Ranaweera, Ch., McDougall, G., Bansal, H. (2005). A model of online customer behavior during the initial transaction: Moderating effects of customer characteristics. Marketing Theory, 5(51), 51-74. 
5. Dixon, M. J., Thompson, G. M. (2015). Bundling and Scheduling Service Packages with Customer Behavior: Model and Heuristic. Production and Operations Management, 25(1), 36-55.

6. Radu, V. (2019, November 26). Consumer behavior in marketing - patterns, types, segmentation. Omniconvert. Retrieved from: https://www.omniconvert.com/blog/consumer-behavior-in-marketing-patterns-typessegmentation.html

7. Turzo, J. (2020, April 15). Štyri elementy, ktoré ovplyvnila pandémia koronavirusu. Retailmagazin. Retrieved from: https://www.retailmagazin.sk/obchodnik/4619-styrielementy-ktore-ovplyvnila-pandemia-koronavirusu

8. Sheth, J. (2020). Impact of Covid-19 on consumer behavior: Will the old habits return or die? Journal of Business Research, 117, 280-283,

9. Vithayathil, J., Dadgar, M., Osiri, JK. (2020). Social media use and consumer shopping preferences. International Journal of Information Management, 54, Article Number 102117.

10. Schaarschmidt, M., Konsgen, R. (2020). Good citizen, good ambassador? Linking employees' reputation perceptions with supportive behavior on Twitter. Journal of Business Research, 117, 754-763.

11. Lombart, C., Millan, E., Normand, JM., Verhulst, A., Labbe-Pinlon, B., Moreau, G. (2020). Effects of physical, non-immersive virtual, and immersive virtual store environments on consumers' perceptions and purchase behaviour. Computers in Human Behavior, 110, Article Number 106374.

12. Szymkowiak, A., Guzik, P., Kulawik, P., Zajac, M. (2020). Attitude-behaviour dissonance regarding the importance of food preservation for customers. Food Quality and Preference, 84, Article Number 103935.

13. Pygmalions (2020, April 24). Ako sa zmenilo nákupné správanie počas pandémie? Strategie. Retrieved from: https://strategie.hnonline.sk/marketing/2136141-ako-sazmenilo-nakupne-spravanie-pocas-pandemie

14. Rosenbaum, L. (2020, April 16). Sociálny dištanc proti koronavírusu môže trvat' až do roku 2022, hovoria vedci. Forbes. Retrieved from: https://www.forbes.sk/socialnydistanc-proti-koronavirusu-moze-trvat-az-do-roku-2022-hovoria-vedci/

15. Jucha, P., Corejova, T. (2020) Elektronický obchod v čase pandémie koronavírusu. Pošta, Telekomunikácie a Elektronický obchod, $15 \quad$ (1). https://fpedas.uniza.sk/ ks/casopis/pdf/I2020/I-2020.pdf

16. Corejova, T., Rovnanova, A., Genzorova, T., Valica, M. (2016). Digital transformation and its impact on brand. In: Petranova, D., Cabyova, L., Bezakova, Z. (Eds.), Marketing identity: brands we love : conference proceedings from international scientific conference (pp. 54-65). Smolenice: Marketing Identity.

17. Kun-Huang Huarng, Tiffany Hui-Kuang Yu (2020). A comparative study of online consumer behavior: a tale of two research methods. International Journal of Emerging Markets, 4, 716-727.

18. MNFORCE and Datamar International. (2020). Výskum spotrebitelskej nálady vplyvom. Nalada 2020. Retrieved from: https://www.nalada2020.eu/sk.html 